\title{
RISK AND PROFITABILITY OPTIMIZATION OF INVESTMENTS IN THE OIL AND GAS INDUSTRY
}

\author{
A. DOMNIKOV, P. KHOMENKO, G. CHEBOTAREVA \& M. KHODOROVSKY \\ Academic Department of Banking and Investment Management, Ural Federal University, Russia.
}

\begin{abstract}
Finding an optimum ratio of return and risk of investment projects is the key problem in overcoming the unfavorable conditions of oil prices and the reduction of profitability of the oil and gas industry. Search for investment opportunities associated with the potential willingness of oil companies to raise funds in new projects, leading to the need for improved tools maximize the return of investment activity in the conditions of uncertainty and risk. In the article the authors propose an original approach which allows solving the problem of formation of a portfolio of investment projects that achieve the maximum return on the risks assumed. The approach includes a method for determining the credit quality of the investment project on the basis of probability of default. This method is based on a comprehensive multivariate analysis of the investment project. Factors model aimed at the country and regional analysis, identification of foreign exchange, operational, technological and financial risks of the project and obtaining the integral evaluation of the project credit. The approach also includes economic capital modeling based on the MV-model (Merton-Vasicek-model), allowing achievement of the target level of creditworthiness of an oil and gas company in the long run. The proposed method of estimating project profitability is based on RAROC (risk-adjusted return on capital) methodology which enables calculation of profitability of projects based on their riskiness. The results can be used by management of oil and gas companies, investors and analysts in making financial decisions.

Keywords: default, investment, long-term sustainability, Merton-Vasicek method, oil and gas company.
\end{abstract}

\section{INTRODUCTION}

Given the current dynamics to date, the oil and gas industry is characterized by the following relevant risks of key importance for investment such as unstable price situation, growth of the stocks extraction cost or development of alternative energy sources, improvement of energy technologies.

Accounting for these risks plays a key role in determining the return on investment and making investment decisions. However, for potential investors, along with the yield and payback period, there is an undated question: how sustainable is a particular oil and gas company, what are its development outlooks, and what specific risks the investment project may run into.

Therefore, there is an emerging complicated problem consisting not only in the study into latent risks run by an oil and gas company, but also in the analysis of the company's longterm financial sustainability in the realisation of multidirectional investment projects, taking into account the probability of default and volatility of mineral commodity markets. The objective of the presented paper is to study the impact of the risk's level and profitability of investment projects in the oil and gas sector on the long-term sustainability of the industry company and optimization of these processes.

The undertaken study resulted in the developed proprietary approach to the assessment of oil and gas company's economic capital, which allows online identification of the most critical points in the implementation of respective investment projects, and development of a corporate long-term financial sustainability management program. 


\section{DEVELOPMENT OF LONG-TERM SUSTAINABILITY FOR OIL AND GAS COMPANIES}

The current economic literature gives a variety of definitions for long-term sustainability of a company. Within the framework of this study, defining its principal development vector, the long-term financial sustainability of an oil and gas company should be deemed to be the ability of the business to ensure the continuity of performance, the stability of revenue generation with the continued capability of cost optimisation and high level of innovation activity considering sustainable competitive edges, unique market position and destabilising environmental exposure.

The basic factors affecting the development of long-term financial sustainability of an oil and gas company were listed above. Nevertheless, the modern risk-oriented approach to assessment of corporate sustainability defines a number of additional factors, such as: level of assumed risk within the implementation of a specific investment project undertaken by an oil and gas company, related probability of the project default, as well as the company's ability to cover the default losses, i.e. the amount of economic capital [1,2].

\subsection{The role of economic risk management in industrial development}

The internal and external environment of an industrial company is equally a source of opportunities for the realization of competitive advantages and a source of hazards for industrial development. Economic impacts from the implementation risks can be the following [2]:

1. Direct losses associated with material damage inflicted on a company (losses of resources, fixed assets, intangible assets).

2. Deficiency in planned profit, cash flow due to the reduction of income, excess spending growth, loss of benefit, use of investment alternatives.

Due to the complexity of the technological environment, economic and financial relations, the growing of uncertainty risk factors as the main problem of risk management in industrial development acquire special significance for long-term business planning and strategy implementation.

The variety of risks that track the development of industrial companies includes several economic risks. The quality of risk management is defined by:

1. The continuity of supply, which is the main condition for regular industrial production.

2. The stability of production sales and operating cash flow of the business.

3. The efficiency of investment activity, adherence to which is achieved by proper selection of investment projects and business portfolio of a company.

4. Business supporting the necessary financial resources for current operations, capital programs, technological level maintenance and modernization of production capacities.

In this regard, sustainable industrial development is impossible without an effective mechanism for the identification, evaluation and management of economic risks.

2.2 Specifics of investment risks run by oil and gas companies as an assessment factor for long-term financial sustainability

Within the framework of this study, twelve principal risks were considered including those of latent nature, which emerge during implementation of investment projects undertaken by oil 
and gas companies. All specific risks are divided into two groups according to the level of impact on the oil and gas company: exogenous risks and endogenous risks [2, 3]. Below is given a brief characterisation of each of the groups.

The exogenous risks are independent of operations conducted by the oil and gas company and are beyond its control. In this study, the following risks are considered as such:

- The risk of "state attractiveness" characterised by the investment climate of a country where the company is operating $\left(X_{l}\right)$.

- The risk of "regional attractiveness" characterised by the investment climate and developmental trends of a region where the company's investment project is being implemented $\left(X_{2}\right)$.

- Mineral resource-related risk: global trends in the overall sector development considering the volatility of mineral commodity market $\left(X_{3}\right)$.

- Government support-related risk: pursuit by a government in the country where the company is situated to make public investments, guarantee a certain level of return on private investments $\left(X_{4}\right)$.

- Currency-related risk characterised by potential losses for the company as a result of adverse changes in foreign exchange rates $\left(X_{5}\right)$.

The endogenous risks are the outcome of assessment and analysis into all spheres of operations and financial activities undertaken by the oil and gas company. The following risks are considered as such:

- "Operating" risk: general deterioration of the company's financial standing as a result of inefficient operating activities $\left(X_{6}\right)$.

- Investment project-related risk: risk of increase in company's financial losses related to the implementation of investment projects $\left(X_{7}\right)$.

- Investment risk: risk of general deterioration of company's financial standing as a result of inefficient miscellaneous investment activities $\left(X_{8}\right)$.

- Underfunding risk: risk related to the investment project cost growth $\left(X_{9}\right)$.

- Risk of contingent financial losses which are difficult to forecast and are of a latent nature $\left(X_{10}\right)$.

- Environmental risk characterised by excessive industrial emissions to the environment $\left(X_{11}\right)$.

- Technology-related risk: plant and equipment renewal rate $\left(X_{12}\right)$.

The practical assessment and analysis of each of the presented risks are given in Section 5 of this article.

\section{RATING MODEL FOR ASSESSMENT OF INVESTMENT PROJECTS}

A general methodology for assessment of long-term sustainability of investment projects based on calculation of company's economic capital was presented by the authors in a number of works [1]. One of the components in this approach is a calculation of default probability for analysed investment projects, inextricably linked with the concepts of default modeling.

Review of the basic concepts is presented in paragraph 3.1. 


\subsection{Methods of modeling risks of investment projects}

Quantitative credit risk measurement has for a long time been one of the most urgent tasks of risk management in modern companies. In this connection, there has appeared a large number of studies on the issue of modeling of credit scoring of companies and investment projects. To build models of individual assessment of credit risk is an essential criterion for the credit risk indicator used by the method and model development. As a result, use may be made of a model limited to use in its building of the borrower's financial condition (default, no default) as an indicator of credit risk, as well as models developed on the basis of market information about the borrower. As part of the approach, using the financial condition of a borrower as a risk indicator based on the criterion of the nature of risk factors, prediction microeconomic, macroeconomic and actuarial models may be identified. The model based on the market information proceeding from similar criteria, applies the methods based on market prices of shares on the basis of yield spreads of bonds, as well as the risk prediction model based on the CDS (credit default swap) spreads. Let us consider the basic approaches and models of credit risk assessment in more detail.

The generally accepted approach to assessing the credit risk that has gained wide popularity among a large number of banks, investment analysts, consulting firms is the microeconomic approach. This approach is also termed balance or approach based on financial performance, which limits its content, because bankruptcy risk assessment in the framework of this approach considers not only the factors of financial statements of a project company, but also on its qualitative and economic characteristics [4].

Development of micro-economic approach has its origin in the 30s of the last century, when analysts and researchers, on the basis of observations of stable companies and firms experiencing financial difficulties, noted significant differences in their financial performance.

Fundamental research in the framework of this approach was the work of P. Fitzpatrick [5], who compared 13 financial indicators for the success and failure of firms and concluded that the most significant in predicting financial difficulties were the ratio of equity and debt, as well as net income and equity capital. Initial risk prediction models were constructed to assess the companies, but in the subsequent approach to the project was the use of companies and investment projects in particular. Most of the data models are widely used in the $2000 \mathrm{~s}$ and used to build equations on the basis of a wide number of factors, including such indicators as financing structure, coverage, design of liquidity, availability of experience in implementing and marketing component [6].

Development of Neurocybernetics apparatus and methodology of neural networks was the impetus to search for ways of its office applications to solve diagnostic problems and predicting bankruptcy of investment projects and project companies. Development of bankruptcy prediction models based on neural networks was started in the 90s of the last century and continues to the present day. The model based on neural networks is an artificial neural network - a set of interconnected artificial neurons. Artificial neurons convert input pulses according to the values of the weights of synapses in the transfer function, which are the output neuron. The weights of the neurons are movable parameters and can change during the self-learning neural network. The neural network method has a number of significant advantages:

- Ability to detect latent and non-linear relationships between variables.

- The ability to adapt to changes in the environment due to the ability to learn. 
- System fault tolerance of individual elements.

However, it should identify a number of drawbacks hindering the wider application of this method in practice:

- The difficulty of explaining the hidden connections, the possibility of conflict with the theory and common sense.

- Complexity of the machine tool, lack of understanding of the work and the organization of end-users network mechanisms.

- Complexity of the neural network architecture increases the likelihood of illogical behavior of the network.

- Formation of a training sample to attain correct functioning of the neural network associated with significant costs, and time and money expenditures.

- Neural networks do not guarantee the optimal solution found.

Models based on market indicators, in contrast to the models used as a risk indicator of the financial condition of the borrower, are based on the bond market information, stocks and derivatives. Information from the financial markets reflects the expectations of the parties regarding the riskiness of financial instruments and their issuers. The market, which takes into account every time a lot of financial, information in general gives an objective assessment of the company's risks. In this class of models, the spread of the approach is based on the option pricing theory, which has won wide popularity among the banks and rating agencies around the world. For the first time, the idea of this approach for estimating the probability of bankruptcy had been proposed by F. Black and M. Scholes in 1973. An important role in the development of this model belongs to Robert Merton and company KMV (Kealhofer, McQuown and Vašíček Corporation, now it is Moody's Analytics). Within the Merton model, or the KMV model, the key factors are the cost of bankruptcy forecasting firm's assets, risk assets and financial leverage. The cost of the company's assets can be expressed in terms of the market value of equity and debt instruments. The risk factor of assets is put into the model via the volatility of the value of the company's assets. Financial leverage is determined by the structure of funding. The Merton model key tenet acts on the assumption that the share of the company is equal to the option "Call" on the underlying asset with a strike price equal to the nominal debt of the company. Underlying asset in this situation are the assets of the company. For the owner of the option payoff corresponds to the difference between the market value of assets and the value of liabilities owed to creditors, and the loss is limited to the market value of owned assets. At the same time the gain is limited by the lender interest charged for the use of liabilities and losses included as accrued interest, and the body of the debt. If you allow excess of the amount of liabilities over the market value of the company's assets, the use of the option becomes unprofitable to the buyer, the assets are transferred to the creditor, in the reverse situation, the settlement of liabilities is carried over to creditors.

One of the Merton models of development is the construction of hybrid models to predict the probability of bankruptcy. In the early 2000s, the first hybrid models were proposed, combining both market information and data of financial statements of companies to predict the probability of default. These models are the logical development of the Merton model to assess the probability of bankruptcy of a company. In 2000, Shobehart, Stein, Mikityanskaya, and Li developed a hybrid model for evaluating the probability of bankruptcy for public non-financial companies in the US [7]. The sample consisted of 14,447 public companies, 
923 of which defaulted. This model was aimed at early warning of changes in credit quality among corporate borrowers. The developed model is used the company's credit rating, information, financial statements, market information (the volatility of stock prices and the rate of growth of capital) and macroeconomic variables. Similarly, the Merton model and the model of Shobehart et al. provides an estimate of the distance to default, which subsequently determines the probability of the borrower's bankruptcy. The hybrid model of Shobehart et al. has advantages compared to the net structural model, which gives an advantage in precision in estimating the probability of default by the use of financial reporting data and credit ratings.

As a result of the securitization of financial markets - increasing the importance of the bond market as a source of funding for the company, it is the development of models that use the bond market indices as an indicator of the credit risk. These may include the prices for debt securities and interest rates. The use of models based on the market price of bonds is based on the risk-neutral approach, which considers that the risk-free financial instruments and risky investments subject to equity yields are still attractive for investors. In connection with this, the risk-neutral valuation of bonds is determined based on discounted future cash flows of the bonds at the risk-free interest rate.

The main hypothesis of models based on credit spread is that the yield spread, which reflects the difference between the yields on corporate bonds and risk-free interest rate, is determined by the value of the credit risk posed by these obligations. The growth of the probability of default increases the yield spread, and decrease of the probability of default leads to a decrease in the spread. At the same time, the yield spread is approximately estimated as the product of probability of default and the level of losses in case of default.

Credit risk is not the only factor that determines the amount of yield spreads on bonds, but many studies confirm the presence of a statistically significant relationship between the characteristics of the financial position of the company and the risk factors and the value of the bond spread [8].

Development of the market of derivative financial instruments - CDS has created conditions for the emergence of yet another class of market models. CDS is a derivative financial instrument that provides insurance against default on debts. A CDS buyer pays a premium to the issuer for credit risk, and in case of default on the obligations, the issuer shall pay the purchaser compensation equal to the amount of debt and interest to maturity. Research CDS as an indicator of the risk of the project company presented empirical studies of CDS spreads determinants. At the same time, there are two approaches: those based on structural and on reduced form models. On the basis of research on corporate bond spreads of CDS, the researchers found that the main factors are the changes in CDS spreads of the individual features of the company: its rating, volatility of assets, changes in stock prices, financial leverage and market capitalization. The Benkert model [9] emphasizes the leading role of the volatility of the assets in explaining the dynamics of credit spreads. Abid and Naifar are five different variables that affect CDS spreads: credit scores, time to CDS contract maturity, the value of risk-free interest rates, the slope of the yield curve and volatility of the shares. In their estimate, these variables explain about $60 \%$ of the variation spreads CDS [10]. Models based on the abbreviated forms suggest a default as a fully exogenous events, independent of the balance sheet of the company.

\subsection{Specifics of the rating model for assessment of investment projects}

A widely accepted approach to assessing credit risk, gained wide popularity among a large number of banks, investment analysts, consulting firms, is a microeconomic approach. This 
approach is also called the balance sheet, or an approach based on financial performance, which in our view limits its contents, since to assess the risk of bankruptcy in the framework of this approach not only factors on the basis of the financial statements of the borrower are used, but also the qualitative, economic characteristics of the company. In particular, the importance of assessing the quality of management in the construction of models of credit risk assessment is noted in George. Lopez, Rosner, Fumbles, Leach and Newson [5] who argue that the importance of the qualitative characteristics is in evaluating financial stability in the conditions of manipulation of financial statements in order to conceal the impending bankruptcy. In the context of misreporting data or financial information deficit, the role of high-quality and non-financial factors in the prediction of bankruptcy increases. Development of micro-economic approach has its origin in the 30s of last century, when analysts and researchers on the basis of observations of stable companies and firms in financial difficulties, noticed significant differences in their financial performance. Fundamental research in the framework of this approach was the work of P. Fitzpatrick, who compared 13 financial indicators for successful and unsuccessful firms and concluded that the most significant in predicting financial difficulties were the ratio of equity and debt as well as net income and equity. The best-known model which resulted from the development approach has become the model by W. Beaver, E. Altman, R. Tishow and G. Taffler, J.W. Wilcox, J. Olson [5].

Within the management of long-term financial sustainability for oil and gas companies, the assessment of emerging investment risks run by the projects offered for implementation is made by using a logit model. This involves a logistic transformation applied to the forecasting, based on the maximum likelihood (ML) method [11].

General form of the logit model is given in eqn (1) [11]:

$$
P D=\left(y_{i}=1\right)=\frac{1}{1+e^{-z}},
$$

where PD - the investment project default probability; $\left(\mathrm{y}_{\mathrm{i}}=1\right)$ - the case where the investment projects end in default; $\mathrm{z}=\left(\mathrm{b}_{0}+\mathrm{b}_{1} \cdot \mathrm{X}_{\mathrm{i} 2}+\ldots+\mathrm{b}_{\mathrm{n}} \cdot \mathrm{X}_{\mathrm{in}}\right) ; \mathrm{X}_{\mathrm{ij}}$ - the value of financial indicator $\mathrm{j}$ for investment project $\mathrm{i} ; \mathrm{b}_{\mathrm{j}}$ - the estimated significance of factor $j$.

The basis for the logit model is data characterising the borrower's financial activity. As a rule, the logit model includes at least ten financial variables for analysis: equity to debt ratio, return on total assets, net earnings index, dummy variable characterising the sign of net earnings for the previous two years, etc. [12].

Apart from the basic financial indicators, the logit model considers the combination of exogenous factors (investment climate in the country and region, level of sector governmental support etc.), which play a key role in the process of financial decision-making by the investor.

The use of the logit model results in the ultimate ranking of investment projects according to the default probability.

3.3 Application of rating model to the assessment of investment projects undertaken by oil and gas company

The model includes twelve risks described above; each of them has its own particular features within each of the investment projects of interest.

Given the difficulties in acquisition of statistical information on default probabilities for similar investment projects, this study made use of the expert assessment method. A questionnaire 
poll was conducted among heads of departments and divisional superintendents of an oil and gas company in Russia with respect to the assessment of presented risks according to the specified scale [13].

This assessment resulted in the specification of a logit model for the oil and gas company, applicable to each project $\mathrm{i}$. The refined $\mathrm{z}$ parameter in eqn (1) will assume the following form, such as eqn (2) [2]:

$$
\begin{aligned}
z= & 0.5578+1.0012 \cdot X_{i 1}+0.8794 \cdot X_{i 2}+0.1478 \cdot X_{i 3}+0.9841 \cdot X_{i 4}+0.5878 \cdot X_{i 5}+0.6587 \cdot X_{i 6} \\
& +1.0231 \cdot X_{i 7}+1.0488 \cdot X_{i 8}+1.0488 \cdot X_{i 9}+0.8974 \cdot X_{i 10}+0.2358 \cdot X_{i 11}+0.9875 \cdot X_{i 12}
\end{aligned}
$$

\section{BASIC COMPONENTS OF CAPITAL RISK MODEL}

The key parameters characterising an investment project for the purposes of assessing the economic capital are the following $[1,2,4,11,12,14]$ :

PD - probability of default. A key indicator characterising the project risk level and reflecting the potential probability of the investment project default.

LGD - loss given default. Expected average relative losses to be incurred by the company in case of the investment project default. In case of default, this portion of the investment project cost will be lost irrecoverably.

EAD - exposure at default. This characterises an absolute value of the investment project and is determined by the project's full actual or forecast capital, current and other costs.

$\mathrm{M}$ - maturity. An average period during which the risk maintains its position. This is determined by the project investment phase duration. The prolonged investment phase will lead to growth of risks due to increased uncertainty of the implementation results. The shortened investment phase will lower the overall project risk.

The PD assessment model as a component of capital risk was described above. The economic capital is calculated considering the probability of investment project default.

The PD parameter is assessed in 4 steps:

1. Data pre-processing for modeling is made based on the implementation statistics for the company's investment projects over an extended period (at least 3 years). The key parameters for assessment may be the LGD for each defaulting project or the RR (recovery rate) characterising the percentage of the project cost, which was recovered as a cash flow following the project default.

2. Classification of investment projects by the criterion of LGD difference significance. Clustering of investment projects may be based on the criteria of scale, objectives, effect types, implementation periods, cash flow types, state of the economy and other criteria. The final clustering shall be based on the criterion of significance of average differences in the sample, which may be estimated using the Student t-test, Fischer F-test, Kolmogorov-Smirnov test, Mann-Whitney U-test [15].

3. Formulating the LGD distribution for each cluster. Based on the LGD statistical data the distribution for each classification group is formulated.

4. Estimation of LGD distribution form and determination of key parameters. At this step the distribution form is estimated and parameters for LGD modeling in each classification group are determined. The distribution form may be estimated using the chi square test, Anderson-Darling test, Kolmogorov-Smirnov test [15]. 
From henceforth, when modeling the economic capital by the Merton-Vasicek model the LGD numeric values will be used, however, for calculation of capital risk by simulation modelling method, LGD may be used as a random variable with parameters specified in Section 4.

The maturity characterises the penalty on the prolonged investment phase. Additional adjustment for the capital risk for the project duration more than 1 year is made using eqn (3) [11]:

$$
M=\frac{1+T-2.5 \cdot b(P D)}{1-1.5 \cdot b(P D)},
$$

where $\mathrm{M}$ - maturity, $\mathrm{T}$ - investment project risk horizon, $\mathrm{b}(\mathrm{PD})=0.00852-0.05489 \cdot \ln (\mathrm{PD})$.

Shift and slope parameters for the maturity may be estimated by the company itself for different types of investment projects, based on the statistical data. Also, the model may be adjusted taking into account the investment project average duration [16].

Also, the concentration factor for the company's investment projects may be considered a penalty, however, the concentration modelling is beyond this study.

\section{APPLICATION OF ECONOMIC CAPITAL ASSESSMENT MODEL FOR AN OIL AND GAS COMPANY}

Supposing that the investment program of an oil company includes 5 investment projects with the source parameters as given in Table 1.

Given the requirement to manage the long-term sustainability of oil and gas assets, determination of the financial sustainability strategic level, which is the long-run target, is the important stage of risk management. This level of financial sustainability may be determined using a target long-term credit rating the company is seeking to obtain. The company value and development strategy becomes an important factor in the risk assessment and management. Each credit rating may be assigned a certain level of PD, depending on the forecasting horizon. One of the matching options for credit rating and probability of default is given in Table $2[17,18]$.

The probability of default determines the level of confidence required to calculate the contingent losses and economic capital of an oil and gas company, which is calculated using eqn (4):

$$
\gamma=1-P D,
$$

where $\gamma$ - the confidence level determining the probability of smash up non-occurrence; PD the probability of default corresponding to the target credit rating.

Table 1: Key parameters of investment project under implementation.

№ Projects

1 Replacement of cold water pump

2 Upgrading of main oil pipeline

3 Oil storage construction

4 Upgrading of oil refining department at Refinery

5 Upgrading of petrol station chain
Full cost, Project implementation Probability of \$ million period, years default, $\%$ 
Table 2: Correspondence between the probability of default and credit rating.

\begin{tabular}{lccc}
\hline Rating & 1-Y PD $(\%)$ & 3-Y PD $(\%)$ & 5-Y PD $(\%)$ \\
\hline AAA & 0.008 & 0.03 & 0.1 \\
AA & 0.04 & 0.16 & 0.28 \\
A & 0.16 & 0.4 & 0.58 \\
BBB & 0.3 & 1.4 & 3 \\
BB & 1.15 & 8.6 & 15 \\
B & 5.8 & 15.4 & 32.6 \\
CCC or lower & 26.57 & 45.5 & 60 \\
\hline
\end{tabular}

Based on the LGD distributions, an estimate of statistically distinctive LGD basic parameters for each type of investment projects was obtained. The distribution is presented in Fig. 1 and Table 3.

The Merton-Vasicek model $[4,11]$ was used as a method for estimating the economic capital. The correlation coefficient between the project indicators and macro indicators, which allows separating the idiosyncratic risk from the systematic risk, is estimated individually for each the project type. In this model the reliability parameter is specified at a level of $99,97 \%$ which corresponds to the target credit rating BBB. The economic capital conception is presented in Fig. 2. The company's economic capital is calculated using eqn (5) [1]:

$$
C a R=E A D \cdot L G D \cdot\left(N \cdot\left(\frac{N^{-1}(P D)+\sqrt{R} \cdot N^{-1}(\alpha)}{\sqrt{1-R}}\right)-P D\right),
$$
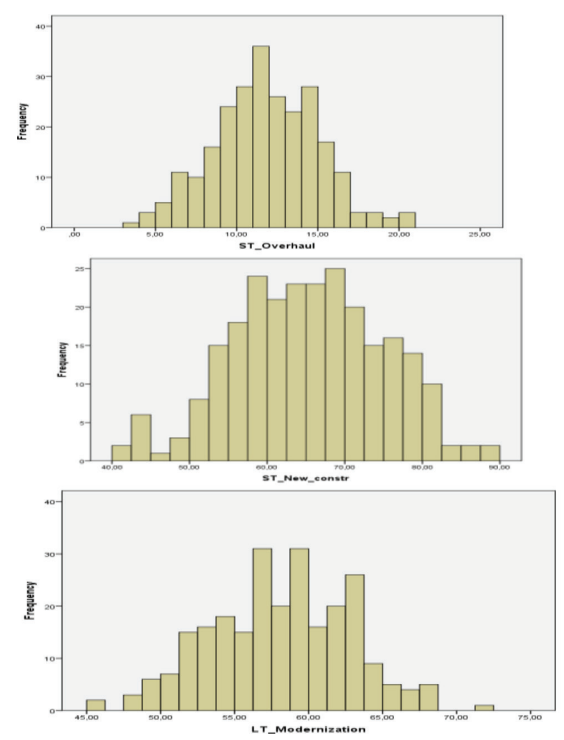
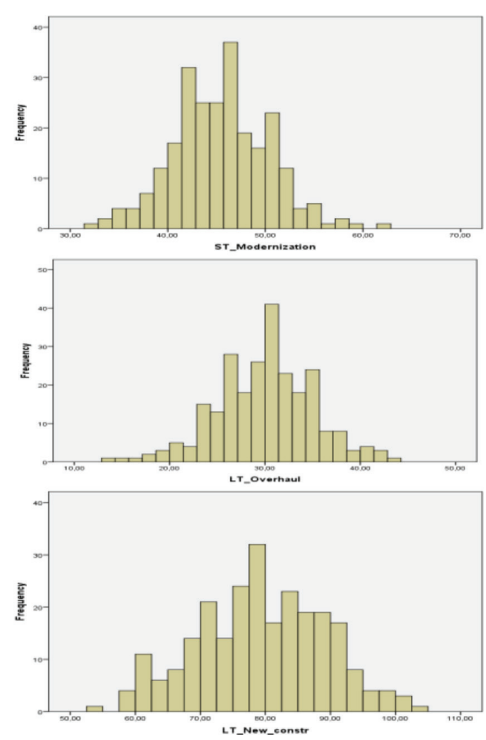

Figure 1: LGD distribution for main types of investment projects. 
Table 3: LGD estimates for main types of investment projects.

\begin{tabular}{lccc}
\hline Project duration/Project type & Overhaul (\%) & Upgrading (\%) & New construction (\%) \\
\hline Short-term & 12 & 45 & 65 \\
Long-term & 30 & 58 & 80 \\
\hline
\end{tabular}

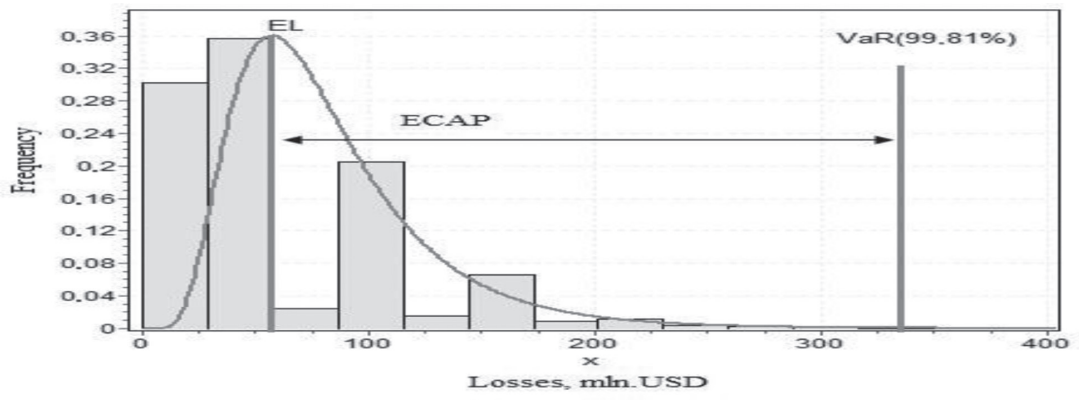

Figure 2: The economic capital conception.

Table 4: Calculation of capital risk for different levels of financial sustainability.

\begin{tabular}{lccrccrrrr}
\hline Project & EAD & $\mathrm{T}$ & $\mathrm{PD}$ & $\mathrm{LGD}$ & $\mathrm{R}$ & $\mathrm{CaR}_{\mathrm{AAA}}$ & $\mathrm{CaR}_{\mathrm{BBB}}$ & $\mathrm{CaR}_{\mathrm{BB}}$ \\
\hline Replacement of cold water pump & 10 & 0.3 & 0.035 & 0.12 & 0.1 & 0.19 & 0.15 & 0.03 \\
Upgrading of main oil pipeline & 45 & 2 & 0.081 & 0.58 & 0.25 & 12.11 & 10.26 & 3.43 \\
Oil storage construction & 35 & 2 & 0.085 & 0.65 & 0.2 & 9.97 & 8.46 & 3.31 \\
Upgrading of oil refining & 120 & 4 & 0.055 & 0.58 & 0.55 & 28.77 & 25.82 & 0.15 \\
department at Refinery No 1 & & & & & & & & \\
Upgrading of petrol station chain & 30 & 2 & 0.054 & 0.58 & 0.62 & 6.38 & 5.95 & -0.06 \\
Total: & & & & & & 57.41 & 50.64 & 6.85 \\
\hline
\end{tabular}

where $C a R$ - company's capital risk; $N$ - standard normal distribution function; $R$ - coefficient of correlation between the project (company) indicators and the overall state of economy; $\alpha$ - level of reliability.

The calculation of capital risk required to attain sustainability corresponding to AAA, $\mathrm{BBB}, \mathrm{BB}$ ratings is presented in Table 4. The calculations have shown that the higher is the target corporate credit rating, the higher requirements to capital are set by the model. Thus, to match AAA credit rating, the capital required to cover the losses from the implementation of investment projects is $\$ 57.41 \mathrm{~m}$, to match $\mathrm{BBB}$ rating, $\$ 50.64 \mathrm{~m}$, and to match $\mathrm{BB}$ rating, $\$ 6.85 \mathrm{~m}[19]$.

The results of the estimated required risk capital value can be used to make investment decisions. As an indicator for the selection of projects indicator RAROC can be used, the methodology of which is disclosed in [20]. Indicator RAROC, which takes into account the ratio of economic benefits and risks, it is advisable to compare with the indicator HR (hurdle rate), describing the required return on equity. If the value exceeds the RAROC hurdle rate, the investment creates value if RAROC $<\mathrm{HR}$, the price collapses. The calculation of RAROC for each project is presented in Table 5 . 
Table 5: Evaluation of RAROC portfolio of investment projects.

\begin{tabular}{lrrrrrr}
\hline Project & EL & ECAP & NI & $\begin{array}{r}\text { RAROC } \\
(\%)\end{array}$ & $\begin{array}{r}\text { HR } \\
(\%)\end{array}$ & $\begin{array}{c}\text { RAROCspr } \\
(\%)\end{array}$ \\
\hline Replacement of cold water pump & 0.27 & 0.66 & 0.34 & 11 & 10 & 1 \\
Upgrading of main oil pipeline & 1.44 & 3.40 & 1.92 & 14 & 10 & 4 \\
Oil storage construction & 1.93 & 8.46 & 2.10 & 2 & 10 & -8 \\
Upgrading of oil refining department & 3.83 & 25.82 & 6.93 & 12 & 10 & 2 \\
at Refinery No 1 & & & & & & \\
Upgrading of petrol station chain & 0.94 & 5.95 & 1.06 & 2 & 10 & -8 \\
\hline
\end{tabular}

The results show which projects are effective in view of risks, and which are unprofitable and destroy the value of the business. So, to implement suitable projects, Replacement of cold water pump, Upgrading of main oil pipeline, Upgrading of oil refining department at Refinery No 1 are appropriate. The project for the Oil storage construction and Upgrading of petrol station chain are destroying the value of the business, leading to implementation of a high risk and are inappropriate. Of course, a number of projects are complex and embedded in the production processes, in such situations RAROC assessment can be made on a portfolio of investment projects, and the decision will be made regarding the multiple portfolios of investment projects.

\section{CONCLUSIONS}

The business competitive position largely depends on its ability to perform in a sustainable manner and to generate cash flows. In this aspect, the key issue is the risk management problem, the solution of which is a pre-requisite for ensuring the long-term sustainability of companies. This problem acquires a special significance under conditions of implementing the investment projects, which may either enhance the business efficiency and scale or lead the company to collapse. The capital management model which is widely used and commonly recognised in risk management is the basis for the approach offered by the authors to the risk management for oil and gas companies. A model for project default probability assessment was developed based on the rating system; a method is offered for estimation of capital risk key components, i.e. losses given default, exposure at default and maturity.

The research contribution is as follows:

- Based on the study of the medium investment projects revealed that the orientation of the risk is a key factor in the success of the implementation of investment projects and maximizing the value of the oil and gas business;

- Highlights the key factors of economic risk accompanying investment projects in the oil and gas business: risk of "state and regional attractiveness", mineral resource-related risk, government support-related risk, currency-related risk, investment project-related risk, etc.;

- An approach to the evaluation of the profitability taking into account the risk, based on the basis of RAROC, has been adapted for use in assessing the profitability of investment projects in the oil and gas industry, with industry-specific, certain key components of the risk model;

- Disclosed the practical possibility of using the author's approach on the example of the investment program of oil and gas companies. 
The methodological approach to the assessment of investment portfolio risks based on the MV- model proves effective and simple in application, however, a number of lines for modelling capital risk are promising. In particular, it is necessary to develop an approach to estimate the correlation between the investment projects and the overall state of the economy, which implicates the formulation of a multi-factor indicator allowing the global trends and their impact on investment activity to be identified. Also, an important problem consists in the refining of EAD model, which considers the project cost distribution at defaulting. Solution of the said problems will allow ensuring the sustainable development of business under conditions of uncertainty and risk.

\section{ACKNOWLEDGEMENT}

The work was supported by the Act 211 Government of the Russian Federation, contract № 02.A03.21.0006.

\section{REFERENCES}

[1] Domnikov, A., Khomenko, P. \& Chebotareva, G., A risk-oriented approach to capital management at a power generation company in Russia. WIT Transactions on Ecology and the Environment, 186, pp. 13-24, 2014.

http://dx.doi.org/10.2495/ESUS140021

[2] Domnikov, A., Chebotareva, G., Khomenko, P. \& Khodorovsky, M., Risk-oriented approach to long-term sustainability management for oil and gas companies in the course of implementation of investment projects. WIT Transactions on Ecology and the Environment, 192, pp. 275-284, 2015.

http://dx.doi.org/10.2495/ECO150251

[3] Domnikov, A., Chebotareva, G. \& Khodorovsky, M., Evaluation of investor attractiveness of power-generating companies: special reference to the development risks of the electric power industry. WIT Transactions on Ecology and the Environment, 190(1), pp. 199-210, 2014.

http://dx.doi.org/10.2495/EQ140211

[4] Merton, R.C., On the pricing of corporate debt: the risk structure of interest rates. Journal of Finance, 29, pp. 449-470, 1974.

http://dx.doi.org/10.1111/j.1540-6261.1974.tb03058.x

[5] Bellovary, J., Giacomino, A. \& Akers, M., A review of bankruptcy prediction studies: 1930 to present. Journal of Financial Education, 33, pp. 1-42, 2007.

[6] Finnerty, J.D., Project Financing: Asset-Based Financial Engineering, 2nd edn., John Wiley \& Sons: New York, p. 560, 2007.

[7] Sobehart, J.R., Stein, R., Mikityanskaya, V. \& Li, L., Moody's Public Risk Firm Risk Model: A Hybrid Approach to Modeling Short Term Default Risk, Moody's Investor Service, Global Credit Research, Rating Methodology, p. 28, 2000.

[8] Trujillo-Ponce, A., Samaniego-Medina, R. \& Cardone-Riportella, C., Examining what best explains corporate credit risk: accounting-based versus market-based models. Journal of Business Economics and Management, 15(2), pp. 253-276, 2014. http://dx.doi.org/10.3846/16111699.2012.720598

[9] Benkert, C., Explaining credit default swap premia. Journal of Futures Markets, 24. pp. 71-92, 2004.

http://dx.doi.org/10.1002/fut.10112

[10] Abid, F. \& Naifar, N., CDO parameters estimation using market prices. International Research Journal of Finance and Economics, 18, pp. 85-95, 2008. 
[11] Vasicek, O., Loan portfolio value. Credit Portfolio Models, 15, pp. 160-162, 2002.

[12] Ohlson, J.A., Financial ratios and the probabilistic prediction of bankruptcy. Journal of Accounting Research, 18(1), pp. 109-131, 2012. http://dx.doi.org/10.2307/2490395

[13] Domnikov, A., Chebotareva, G. \& Khodorovsky, M., Systematic approach to diagnosis lending risks in project finance. Audit and Finance Analyses, 2, pp. 114-119, 2013.

[14] Gorby, M.B., A risk-factor model foundation for rating-based bank capital rules. Journal of Financial Intermediation, 25, pp. 199-232, 2003. https://doi.org/10.1016/s1042-9573(03)00040-8

[15] Gmurman, V., Probability theory and mathematical statistics. Higher School, 1, p. 479, 1997.

[16] Gurtler, M. \& Heithecker, D., Multi-period defaults and maturity effects on economic capital in a ratings-based default-mode model. Finanz Wirtschaft, 5, pp. 123-134, 2005.

[17] Domnikov, A., Khodorovsky, M. \& Khomenko, P., Optimization of finances into regional energy. Economy of Region, 2, pp. 248-253, 2014. http://dx.doi.org/10.17059/2014-2-24

[18] Khodorovsky, M., Domnikov, A. \& Khomenko, P., Optimization of financing investments in a power-generation company. WIT Transactions on Ecology and the Environment, 1, pp. 45-54, 2014. http://dx.doi.org/10.2495/EQ140061

[19] Peter, C., Estimating loss given default - experiences from banking practise. Springerlink, 2, pp. 143-175, 2006.

[20] Schroeck, G., (eds). Risk Management and Value Creation in Financial Institutions, John Wiley \& Sons, Business \& Economics: England, 2002.

[21] Domnikov, A., Chebotareva, G. \& Domnikova, L., Economic and technological priorities of competitive development of Russian systems of energy cogeneration sources. International Journal of Design \& Nature and Ecodynamics, 11(4), pp. 610-619, 2016. http://dx.doi.org/10.2495/DNE-V11-N4-610-619 